\title{
Efficacy of Pre-Harvest Spray of Fungicides and Bioagents on Post-Harvest Storage Diseases of Onion (Allium cepa L.)
}

\author{
R.C. Gupta ${ }^{1 *}$, S. Purushottamn ${ }^{2}$, S. Pandey ${ }^{2}$ and R.P. Gupta ${ }^{1}$ \\ National Horticultural Research and Development Foundation (NHRDF) \\ ${ }^{1}$ Chitegaonphata, Post-Darnasangvi, Niphad, Nashik-Aurangabad Road, Nashik \\ (Maharashtra) India \\ ${ }^{2}$ Regional Research Station, Salaru, Karnal (Haryana) India \\ *Corresponding author
}

\section{A B S T R A C T}

\begin{tabular}{|l|}
\hline K e y w o r d s \\
Black mold, \\
Bioagents, Fungicide, \\
Onion, Pre-harvest, \\
Post-harvest disease
\end{tabular}

The trial was conducted to test the efficacy of pre-harvest spray of fungicides and bioagents on post-harvest storage diseases of onion variety Agrifound Light Red during rabi, 2011-12 and 2012-13 at Regional Research Station (RRS), National Horticultural Research and Development Foundation (NHRDF), Karnal, Haryana. The efficacy of fungicides namely carbendazim + mancozeb, metalaxyl, iprodione, propineb and bioagents like Trichoderma viride, T. harzianum and Pseudomonas fluorescens were tested as pre-harvest foliar spray against post-harvest diseases of onion. The pooled data of storage trials conducted for the period from May to September for 120 days revealed that maximum disease reduction index of black mold was recorded with pre-harvest spray of Metalaxyl@0.1\% (56.25\%) followed by Carbendazin + Mancozeb @ 0.2\% (49.07\%) as compared to untreated control. The study revealed that pre-harvest spray of systemic fungicide alone and combination of systemic and contact fungicide were effective in keeping the low incidence of black mold (Aspergillus niger) in Karnal region of Haryana.

\section{Introduction}

Onion (Allium cepa L.) being a perishable vegetable commodity has a great scope for the attack of post-harvest diseases like basal rot (Fusarium oxysporum), black mold (Aspergillus niger), bacterial brown rot (Pseudomonas aeruginosa) and soft rot (Erwinia carotovora sub sp. carotovora). Out of these black molds an important post-harvest disease of onion and cause heavy losses during storage and reduces the market value of the bulbs. The major damage by $A$. niger is caused during storage which normally goes upto the tune of $80 \%$ and above as reported by Qadri et al., (1982), Gupta and Srivastava (1992) mainly deteriorating the market value of commodity and also resulting in simultaneous losses due to bulb rot. Black mold disease is very common in India wherever onion is stored (Venkatarayan and Delvi, 1951; Tiwari et al., 1984). It causes post-harvest blemishes and rotting of onion grown and stored in hot climate viz., Texas, Sudan, Egypt, and India (Thompson et.al., 1972) as well as in temperate regions like 
United Kingdom where onion is stored for a longer period (Stow, 1975). Onion is cultivated in rabi, kharif and late kharif seasons and maximum area under cultivation is being covered in rabi season. However, onion bulbs produced during rabi season is kept for storage which may be used for seed production, domestic consumption as well as export purpose. The high relative humidity as well as temperature prevailed during the period of onion storage from May to September in Northern parts of India may cause heavy incidence of storage diseases. India has been a traditional exporter of fresh onion with $64 \%$ share of the total export of fresh vegetables. Onion has been exporting to the UAE, Iran, Malaysia, Bangladesh, Sri Lanka, Indonesia, Vietnam, Reunion France and Singapore (Anon, 2008).

Realizing the importance of the above facts, the present study was carried out with the objectives to test the efficacy of pre-harvest sprays of fungicides and bioagents on postharvest storage diseases of onion bulb during rabi, 2011-12 and 2012-13at RRS, NHRDF, Karnal, Haryana.

\section{Materials and Methods}

The field trial was conducted in two consecutive years during rabi, 2011-12 and 2012-13 at RRS, NHRDF, Karnal, Haryana. The size of bed was kept as $3.0 \mathrm{~m} \times 1.2 \mathrm{~m}$. Eight weeks old seedlings of variety Agrifound Light Red were transplanted at spacing of $15 \mathrm{~cm} \times 10 \mathrm{~cm}$. All the recommended cultural practices were uniformly followed for all the treatments. The eight treatment comprised of $\mathrm{T}_{1^{-}}$ Carbendazim+Mancozeb @ 0.2\%, $\mathrm{T}_{2-}$ Metalaxyl@0.1\%, T $3^{-}$Iprodione@0.2\%, T $4^{-}$ Propineb@0.2\%, T5-Trichodermaviride@ 5g/L, T 6 -Trichoderma harzianum @ 5g/L, T $7^{-}$ Pseudomonas fluorescens @ 4g/L and $\mathrm{T}_{8^{-}}$ Untreated control (No spray) were laid out in Randomized Block Design with 3 replications.
The fungicides and bio-agents were sprays at 20 days before harvest of onion crop under field conditions as per treatment for the management of post-harvest diseases of onion. The insecticide deltamethrin @ $0.1 \%$ was sprayed uniformly for thrips control (Pandey et. al., 2007). The irrigation was done at regular intervals to maintain the optimum moisture level in the field. The crop was harvested at bulb maturity and kept in storage after proper drying and curing. The storage was set up for 120 days. The data were recorded on storage disease appeared in bulbs like black mold at 30 days intervals. The data of two consecutive years of rabi, 2011-12 and 2012-13 were pooled, analyzed statistically and presented in Table 1 and Figure 1. The incidence reduction index (\%) of black mold disease of onion was also estimated by following the formula given below.

Incidence in untreated controlIncidence in treatments

Incidence

Reduction Index (IRI) (\%) = ------------ x 100

Incidence in control

\section{Results and Discussion}

\section{Incidence of black mold (Aspergillus niger) of onion bulbs}

The combined data of two years study presented in Table 1 revealed that black mold in onion bulb was recorded after 60 days of storage. The incidence of black mold ranged from $4.34 \%$ to $51.67 \%$ during the storage period from May to September for 120 days. Significantly lowest incidence $(4.34 \%)$ of black mold in stored bulb was recorded in $\mathrm{T}_{1}$ (Carbendazim + Mancozeb @ 0.2\% spray at 20 days before harvest), however, it was found at par with all the treatments except $\mathrm{T}_{7}$ (Pseudomonas fluorescens @ 4g/L spray at 20 days before harvest) after 60 days of bulb storage. 
Table.1 Pre-harvest spray of fungicides and bioagents for management of postharvest diseases of onion

\begin{tabular}{|c|c|c|c|c|c|}
\hline \multirow[t]{2}{*}{ Treatments } & \multicolumn{4}{|c|}{$\begin{array}{l}\text { Black mold Incidence }(\%) \text { in onion } \\
\text { bulbs at different days after storage } \\
\text { (DAS) }\end{array}$} & \multirow{2}{*}{$\begin{array}{l}\text { Incidence } \\
\text { Reduction } \\
\text { Index }(\%) \text { of } \\
\text { black mold }\end{array}$} \\
\hline & 30 days & 60 days & 90 days & 120 days & \\
\hline $\mathrm{T}_{1}$-Carbendazim+Mancozeb @ 0.2\% & 0.00 & 4.34 & 17.50 & 35.00 & 49.07 \\
\hline $\mathrm{T}_{2-}$ Metalaxyl@0.1\%, & 0.00 & 6.67 & 16.67 & 29.17 & 56.25 \\
\hline T3-Iprodione@0.2\% & 0.00 & 5.00 & 30.00 & 41.67 & 38.65 \\
\hline T4- Propineb@0.2\% & 0.00 & 6.67 & 28.33 & 41.67 & 39.12 \\
\hline $\mathrm{T}_{5}$-Trichoderma viride @ 5g/L & 0.00 & 6.67 & 32.50 & 48.34 & 26.39 \\
\hline T6-Trichoderma harzianum @ 5g/L & 0.00 & 6.67 & 36.67 & 51.67 & 27.32 \\
\hline T-Pseudomonas fluorescens@ 4g/L & 0.00 & 10.00 & 35.84 & 50.00 & 22.92 \\
\hline$T_{8^{-}}$Untreated control & 0.00 & 13.34 & 37.50 & 51.67 & - \\
\hline S.Em. \pm & 0.00 & 2.08 & 5.58 & 5.52 & 8.39 \\
\hline CD at $5 \%$ & 0.00 & 4.92 & 13.20 & 13.05 & 19.84 \\
\hline
\end{tabular}

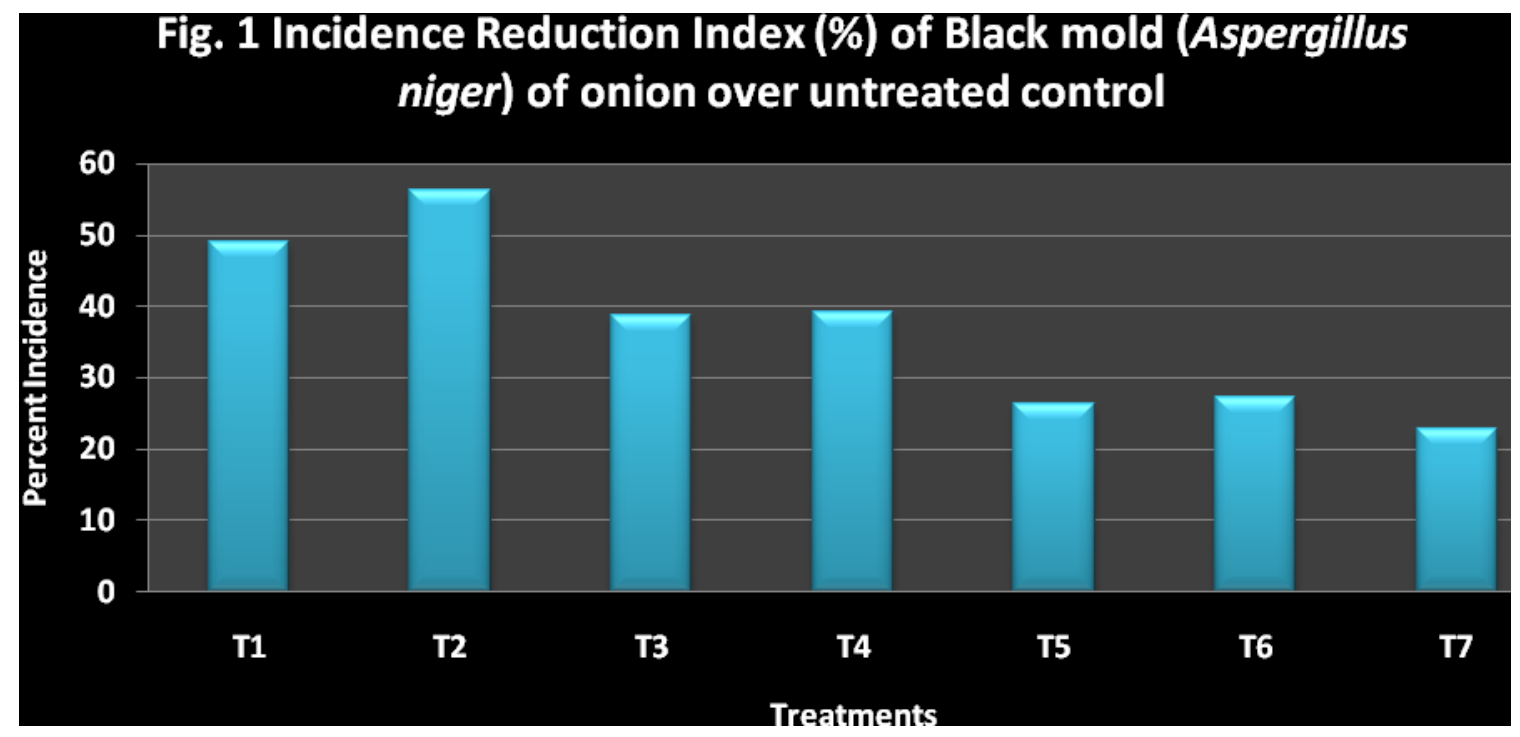

The black mold disease in onion bulbs progress with increasing storage period in all the treatments. After 90 days of bulb storage, significantly lowest black mold incidence (16.67\%) was recorded in $\mathrm{T}_{2}$ (Metalaxyl@ $0.1 \%$ spray at 20 days before harvest) and it was found at par with $17.50 \%$ incidence in $\mathrm{T}_{1}$ and $28.33 \%$ in $\mathrm{T}_{4}$ (Propineb@ $0.2 \%$ spray at 20 days before harvest). The storage data further revealed that the significantly lowest black mold incidence $(29.17 \%)$ was recorded in $\mathrm{T}_{2}$ and it was found at par with $\mathrm{T}_{1}(35.0 \%)$, $\mathrm{T}_{3}(41.67 \%)$ and $\mathrm{T}_{4}(41.67 \%)$ at 120 days after bulb storage (Table 1). The highest incidence of black mold $(51.67 \%)$ in onion bulb was recorded in untreated control at 120 days after storage. The incidence of black mold were recorded in pre-harvest spray of tested bioagents such as T. viride @ 5g/L (48.34\%), Pseudomonas fluorescens@ 4g/L (50.0\%)and 
T.harzianum @5g/L (51.67\%) spray at 20 days before harvest. It shows that the tested bioagents were not effective against postharvest diseases in onion (Table 1). No other post-harvest diseases were observed in stored bulbs in any of the treatments.

\section{Incidence reduction index of black mold (A. niger) of onion bulbs}

The incidence reduction index of black mold was also drawn after 120 days of bulb storage. The maximum IRI $(56.25 \%)$ of black mold was recorded in $\mathrm{T}_{2}$ which was found at par with $\mathrm{T}_{1}(49.07 \%), \mathrm{T}_{3}(38.65 \%)$ and $\mathrm{T} 4$ $(39.12 \%)$ as compared to untreated control at 120 days after bulb storage (Fig. 1). The data shows that pre-harvest spray of Metalaxyl@ $0.1 \%$ followed by Carbendazim + Mancozeb @ $0.2 \%$ at 20 days before harvest effective in keeping the IRI of black mold in Karnal area of Haryana. The lower incidence of black mold was recorded in tested bioagents as preharvest spray which indicates ineffective on post-harvest diseases of onion.

The losses ranged from $22-76 \%$ in stored onion due to incidence of black mold at $27^{\circ} \mathrm{C}$ and $70 \% \mathrm{RH}$ were reported from Texas (Miller and Dillon, 1979). Losses due to black mold ranged from $33 \%$ to $61 \%$ were recorded during summer storage of onion in Japan (Tanaka and Nonaka, 1981). Ahir and Maharshi (2007) further reported that preharvest application of maleic hydrazide and isopropyl phenyl are carbonate effective in keeping the low incidence on black mold (Aspergillus niger) in Rajasthan area again Ahir and Maharshi (2008) again conducted experiment of management of post-harvest diseases of onion and reported that the preharvest spray of companion, a combination of fungicide of carbendazim (12\%) and mancozeb@63\% followed by iprodione @ $0.2 \%$ were most effective in controlling the black mold of onion upto 90 days after storage. Black mold produces brown to sooty black mass of conidia, which can be rubbed off easily on surface of onion bulb. The pathogen gets itself established in bulb tissues and has the ability to produce various enzymes and mycotoxins which are responsible for causing rotting of bulbs. In advance stages of black mold, the entire surface of bulbs turns black and all scales are infected. It causes slow shriveling of the affected scales assuming the brittle texture. It reduces the market value of the bulbs.

\section{References}

Ahir, R.R. and Maharshi, R.P. (2007). Effect of some cultural and crop husbandry practices on black mold (Aspergillus niger) severity of onion bulb in storage. J.Mycol. Pl. Pathol., 37(3):604.

Ahir, R.R. and Maharshi, R.P. (2008). Effect of pre-harvest application of fungicides and biocontrol agents on black mold (Aspergillus niger) of onion in storage. Indian Phytopath., 61(1):130-131.

Anonymous, (2008). Agriculture Year Book. Agriculture Today. The National Agriculture Magazine. pp, 91.

Gupta, R.P. and Srivastava, P.K., (1992). Studies on the onion storage diseases in India. AADF Newsletter, 12 (3): 11-13.

Miller, M.E., and Dillon, R.C. Jr. (1979). Survey of bulb diseases on onions in South Texas. J. Rio Grande Valley. Horlic. Soc., 33:25.

Pandey, Sujay, Pandey, J.G. and Srivastava, K. J. (2007). Management of onion thrips with some insecticidal combinations. Pestology, Vol. XXXI. October: 42-44.

Qadri, S.M.H., Srivastava, K.J., Bhonde, S. R. and Pandey, U. B. (1982). Fungicidal bioassay against certain important pathogens of onion. Pestology, 16 (2): 11-16. 
Stow, J.R. (1975). Effects of humidity on losses of bulb onions (Allium cepa) stored at high temperature. Exp. Agarlic., 11:81.

Tanaka, K, and Nonaka, F. (1981). Studies on the rot of onion bulbs caused by Aspergillus niger and its control by lime applications. Bull. Fac. Agric. Saga Univ., 51:47.
Thompson. A.K., Booth, R.H., and Proctor, F.J. (1972). Onion storage in the tropics. Trop. Res., 14:19.

Tiwari, B.K., Srivastava, K.J., and Qadri, S.M.H. (1984). Aspergillus niger: a potent enemy of onion. Seeds and Farms, 9 (12): 15-16.

Venkatarayan, S.V., and Delvi. M.H. (1951). Black mould of onions in storage caused by Aspergillus niger. Curr. Sci., 20:243-244.

\section{How to cite this article:}

Gupta, R.C., S. Purushottamn, S. Pandey and Gupta, R.P. 2018. Efficacy of Pre-Harvest Spray of Fungicides and Bioagents on Post-Harvest Storage Diseases of Onion (Allium cepa L.). Int.J.Curr.Microbiol.App.Sci. 7(03): 2625-2629. doi: https://doi.org/10.20546/ijcmas.2018.703.303 